\title{
Ripening influences banana and plantain peels composition and energy content
}

T. Happi Emaga $\cdot$ J. Bindelle $\cdot$ R. Agneesens $\cdot$ A. Buldgen $\cdot$ B. Wathelet $\cdot$ M. Paquot

This article is in press in Trop. Anim Health Prod.:

DOI 10.1007/s11250-010-9671-6

T. Happi Emaga $\cdot$ B. Wathelet · M. Paquot

University of Liège, Gembloux Agro-Bio Tech, Department of Industrial Biological Chemistry, 2 Passage des Déportés, 5030 Gembloux, Belgium

T. Happi Emaga

African Research Centre on Bananas and Plantains (CARBAP), PO. Box 832 Douala, Cameroon

J. Bindelle $(\bowtie) \cdot$ A. Buldgen ${ }^{\dagger}$

University of Liège, Gembloux Agro-Bio Tech, Animal Science Unit, 2 Passage des

Déportés, 5030 Gembloux, Belgium

Email : jerome.bindelle@ulg.ac.be

${ }^{\dagger}$ Deceased

R. Agneesens 
Centre wallon de Recherches agronomiques, Section Systèmes agricoles, rue du Serpont, 100, 6800, Libramont, Belgium

\begin{abstract}
Musa sp. peels are widely used by smallholders as complementary feeds for cattle in the tropics. A study of the influence of the variety and the maturation stage of the fruit on fermentability and metabolisable energy (ME) content of the peels was performed using banana (Yangambi Km5) and plantain (Big Ebanga) peels at three stages of maturation in an in vitro model of the rumen. Peels samples were analysed for starch, free sugars and fibre composition. Samples were incubated in the presence of rumen fluid. Kinetics of gas production were modelled, ME content calculated using prediction equation and short-chain fatty acids production and molar ratio measured after $72 \mathrm{~h}$ of fermentation. Final gas production was higher in plantain $\left(269-339 \mathrm{ml} . \mathrm{g}^{-1}\right)$ compared to banana $\left(237-328 \mathrm{ml} . \mathrm{g}^{-1}\right)$ and plantain exhibited higher ME contents (8.9-9.7 MJ/kg of DM) compared to banana (7.7-8.8 $\mathrm{MJ} / \mathrm{kg}$ of DM). Butyrate molar ratio decreased with maturity of the peels. The main influence of the variety and the stage of maturation on all fermentation parameters as well as $\mathrm{ME}$ contents of the peels was correlated to changes in the carbohydrate fraction of the peels, including starch and fibre.
\end{abstract}

Keywords Banana $\cdot$ plantain · peels · in vitro fermentation · nutritive value
Abbreviations
ADF acid detergent fibre
ADL acid detergent lignin
BE Plantain variety «Big Ebanga »
CP crude protein 
DM dry matter

IDF insoluble dietary fibre

IVDMD in vitro dry matter digestibility

ME metabolisable energy

NDF neutral detergent fibre

OMD organic matter digetsibility

SCFA short-chain fatty acids

SDF soluble dietary fibre

TDF total dietary fibre

Ykm5 Banana variety "Yangambi km5" 


\section{Introduction}

In Cameroon, 860,000 tonnes of banana (Musa AAA) and plantain (Musa AAB) were produced in 2008. At the world level, approx. 90 million tonnes of this fruit are produced, mainly in tropical areas such as Africa (13\%), South and Central America (28\%), including the Caribbean, and South and South Eastern Asia (47\%) (FAOSTAT 2010). About $40 \%$ of this production are wastes, mainly peels which can be used for feeding cattle or pigs. Banana and plantain peels are rich in fibre, polyphenols and low in protein but their composition varies according to the species and the variety as well as the maturation (Happi Emaga et al., 2007). During ripening, the chemical composition of the peels undergoes several major modifications. The starch is hydrolysed into simple sugars, but conversely to the edible fraction of the fruit, in peels at later stages of maturation, the simple sugars content often overpasses that of mere starch found in green peels (Happi Emaga et al. 2007). The protein profile of banana is very deficient in lysine, methionine and tryptophane, but the ripeness does not influence the essential AA contents or the profile. The peels contain large quantities of antioxidants like dopamine (80-560 mg per $100 \mathrm{~g}$ in peel) containing $9.14 \%$ of $\mathrm{N}$ (Happi Emaga et al. 2008b, González-Montelongo et al. 2010) which are released as maturation goes on. The tannins content of the peel which act against the availability of proteins in the rumen decreases with ripening as a consequence of a migration of the polyphenols from the peel towards the pulp and the phenolic oxidative degradation by polyphenol oxidases and peroxidases (Bugaud 2009).

According to the desired use, banana and plantain are consumed or locally processed at various stages of maturation which have been classified from stage 1, green skin, to stage 7 , yellow skin with black spots (Happi Emaga et al. 2008b). The stage maturation is likely to influence the nutritive value of the peels and requires investigation in order to allow farmers 
to adapt the diets fed to the animals to the actual nutritive value of the peels. Previous research has been conducted to determine the nutritive value of these peels for livestock (e.g. Negesse et al. 2009), but except Tarkrakoon et al. (1999) who studied the influence of ripening on the nutritive value of banana peels in pigs, the influence of maturation stage on nutritive value has been neglected until now. The present study aimed to quantify the differences in fermentation characteristics and energy content of banana and plantain peels during ripening and relate them to changes in $\mathrm{CHO}$ composition using an in vitro model of the rumen.

\section{Material and Methods}

Sample preparation

Fruit peels from banana (Musa, genotype AAA, Yangambi Km5 "Ykm5") and plantain (Musa, genotype AAB, Big Ebanga "BE"), were obtained from the African Research Centre on Bananas and Plantain (CARBAP, Douala, Cameroon). These fruit peels were obtained at three different stages of ripeness: stage 1 (green), stage 5 (more yellow than green) and stage 7 (yellow with few black spots). These stages correspond to various uses in transformation industries and traditional culinary preparations, e.g. flour produced from plantain is done at stages 1 and 5, while the drying of bananas pulps for dessert is done at stage 7 .

The first two hands of each bunch were collected in the field for experimentation. Fruit stages of maturation were controlled in laboratory at room temperature $\left(20-25^{\circ} \mathrm{C}\right)$. The fruits were washed and separated into pulps and peels. The peels were dried at $60{ }^{\circ} \mathrm{C}$ for $24 \mathrm{~h}$ and ground with a Cyclotec 1093 Sample Mill (FOSS Electric A/S, Hilleroed, Denmark) to pass a $1 \mathrm{~mm}$ sieve. 
In vitro fermentation

In vitro fermentation was performed using the gas test method described by Menke and Steingass (1988). Briefly, $200 \mathrm{mg}$ of banana or plantain peels were placed into a $100 \mathrm{ml}$ Kolbenprober glass syringe. Thereafter, $30 \mathrm{ml}$ of the inoculum prepared mixing the rumen fluid of 2 Red Holstein cows from the herd of the Centre wallon de Recherches agronomiques (Libramont, Belgium) to a buffer solution (Menke and Steingass 1988) was added to the syringes. The syringes were placed in a water-bath at $39 \pm 0.5^{\circ} \mathrm{C}$ for $72 \mathrm{~h}$. During fermentation, gases $\left(\mathrm{CO}_{2}, \mathrm{H}_{2}\right.$ and $\left.\mathrm{CH}_{4}\right)$ and short-chain fatty acids (SCFA; mainly acetate, propionate and butyrate) are produced by rumen microbes. SCFA are buffered by the carbonate ions to release $\mathrm{CO}_{2}$. The released gas volumes (fermentation and buffered gas) were recorded after $2,5,8,12,16,20,24,30,36,48$, and $72 \mathrm{~h}$ of incubation by displacement of the plunger of the syringes in order to measure how fast the different peels were fermented by the microbes. The incubation was repeated a second run. Three syringes containing only inoculum (blanks) were systematically included in each run. The experimental scheme was as the following: ( 2 ingredients $\times 3$ stages of maturation $\times 3$ replicates +3 blanks $) \times 2$ runs.

After $72 \mathrm{~h}$, fermentation broth were centrifuged $(12,000 \mathrm{~g}, 20 \mathrm{~min})$, the supernatant sampled for further short-chain fatty acids (SCFA) analysis and the unfermented residual pellet was analysed for neutral detergent fibre (NDF) content in order to determine in vitro dry matter digestibility (IVDMD) as recommended by Makkar (2004).

Chemical analyses 
Banana and plantain peels were analyzed for their content in DM by drying at $105^{\circ} \mathrm{C}$ for $24 \mathrm{~h}$ (method 967.03; AOAC, 1990), ash by burning at 550 ${ }^{\circ} \mathrm{C}$ for $8 \mathrm{~h}$ (method 923.03; AOAC, 1990), $\mathrm{N}$ by using the Kjeldahl method and calculating the crude protein $(\mathrm{CP})$ content $(\mathrm{N} \times$ 6.25; method 981.10; AOAC, 1990), ether extract with the Soxhlet method by using diethyl ether (method 920.29; AOAC, 1990). NDF in the peels as well as the fermented residues was determined by the method of Van Soest et al. (1991), using $\mathrm{Na}_{2} \mathrm{SO}_{3}$ and Termamyl (Novo Nordisk, Bagsværd, Denmark) with the Fibercap system (Foss Electric, Bagsvaerd, Denmark). The peels were also analyzed for acid detergent fibre (ADF) and acid detergent lignin (ADL) (Van Soest et al., 1991), starch using the method of EWERS (Iso 10520, 1997) and total, soluble , and insoluble dietary fibre (T-, S- and IDF, respectively) contents (method 991.43; AOAC, 1990). Free sugars (sucrose, fructose and glucose) in the peels were quantified via high-performance liquid chromatography (HPLC) by the Dionex DX500 HPLC system, using a Carbopac PA-10 column $(250 \cdot 4 \mathrm{~mm})$.

The supernatants after fermentation were analyzed for SCFA with a Waters 2690 HPLC system (Waters, Milford, MA) fitted with a HPX 87 H column (Bio-Rad, Hercules, CA) and combined to a Waters 2487 Dual Wavelength Absorbance Detector operating at a wavelength of $210 \mathrm{~nm}$.

Calculations and statistical analyses

Gas accumulation curves recorded during fermentation were modelled using the mathematical model proposed by France et al. (1993):

$$
\begin{aligned}
G & =0, \text { if } 0<t<L \\
& =G_{f}(1-\exp \{-\langle b(t-L)+c(\sqrt{t}-\sqrt{L})\rangle\}) \quad \text { if } t \geq L
\end{aligned}
$$


where $G\left(\mathrm{ml} \mathrm{g}^{-1} \mathrm{DM}\right)$ denotes the gas accumulation to time, $G_{f}\left(\mathrm{ml} \mathrm{g}^{-1} \mathrm{DM}\right)$ the maximum gas volume for $t=\infty$ and $L(\mathrm{~h})$ is the lag time before the fermentation starts. The constants $b$ $\left(\mathrm{h}^{-1}\right)$ and $c\left(\mathrm{~h}^{-1 / 2}\right)$ determine the fractional rate of degradation of the substrate $\mu\left(\mathrm{h}^{-1}\right)$, which is postulated to vary with time as follows:

$\mu=b+\frac{c}{2 \sqrt{t}}$, if $t \geq L$

The kinetic parameters $\left(G_{\mathrm{f}}, L, \mu_{t=T / 2}\right.$ and $\left.T / 2\right)$ were compared in the statistical analysis. $T / 2$ is the time to half asymptote when the gas released reaches half of the final gas volume $\left(G=G_{\mathrm{f}} / 2\right)$. At this time, the rate of gas production is in a linear phase, near its maximum.

The organic matter digestibility (OMD, \%) and metabolizable energy (ME, MJ/kg of DM) of the peels were calculated using the following equations (Menke and Steingass 1988):

$\operatorname{ME}(\mathrm{MJ} / \mathrm{kg} \mathrm{DM})=2,20+0,0272 \mathrm{G}_{24 \mathrm{~h}}+0,057 \mathrm{CP}\left(\mathrm{n}=200 ; \mathrm{R}^{2}=0,94\right) ;$

$\operatorname{OMD}(\% \mathrm{DM})=14,88+0,1778 \mathrm{G}_{24 \mathrm{~h}}+0,45 \mathrm{CP}+0,0651 \mathrm{XA}\left(\mathrm{n}=200 ; \mathrm{R}^{2}=0,92\right) ;$

where $\mathrm{G}_{24 \mathrm{~h}}$ is the gas volume produced after $24 \mathrm{~h}$ fermentation $(\mathrm{ml} / \mathrm{g} \mathrm{DM}), \mathrm{CP}$ the crude protein content of the ingredient (\% DM) and XA is the ash content (\% DM).

Statistical analyses of the kinetics parameters were performed by means of an analysis of variance and a classification of means by the Student-Newman-Keuls method using the GLM procedure of the SAS 8.02 software (SAS Inc., Cary, NC, USA), with the following general linear model:

$$
Y=\alpha+S_{i}+M_{\mathrm{j}}+(S \times M)_{\mathrm{ij}}+P_{k}+\varepsilon
$$

where $Y$ is the result, $\alpha$ the mean, $S_{i}$ the effect of the species ( $i=1$ and 2$), M_{j}$ the effect of the maturation stage $(j=1,2$ and 3$), P_{k}$ the random effect of the period $(k=1$ and 2$)$ and $\varepsilon$ is the error term.

\section{Results}


Besides the changes in $\mathrm{CP}$, fat, ash, starch, free sugars and DF contents already described by Happi Emaga et al. (2007), the evolution of the chemical composition of the banana and plantain peels showed that within the fibrous fraction of the peels, the less digestible ADF underwent the sharpest increase with maturation as a consequence of higher lignin content, whatever the variety (from 79 to $150 \mathrm{~g} / \mathrm{kg} \mathrm{DM}$ in plantain and from 73 to $133 \mathrm{~g} / \mathrm{kg} \mathrm{DM}$ in banana) (Table 1). Hemicellulose decreased in plantain and banana, from 63 to $3 \mathrm{~g} / \mathrm{kg} \mathrm{DM}$ and from 53 to $4 \mathrm{~g} / \mathrm{kg}$ DM respectively. NDF and cellulose remained almost constant during ripening. For a same stage of maturation, banana showed higher fibre contents (TDF, IDF, SDF, NDF, ADF and cellulose) and lower starch and free sugars, whatever the maturation stage, than plantain. Hemicellulose and lignin could be considered as similar for both varieties.

Gas accumulation curves recorded during the fermentation of banana and plantain peels by rumen bacteria are illustrated in Figure 1. All fermentation kinetics parameters shown in Table 2 were influenced by the maturation stage $(\mathrm{P}<0.001)$. Fermentation started earlier in mature peels, with lower lag time $(L)$ and half-time to asymptote $(T / 2)$, but faster and more extended fermentations (higher rates and final gas production, $\mu_{t=T / 2}$ and $G_{f}$, respectively) were recorded with green compared to ripe peels (Table 3). The decrease in lag time $(L)$ and half-time to asymptote $(T / 2)$ with maturation was however sharper for banana compared to plantain as indicated by the interaction between the two factors $(\mathrm{P}<0.001)$. At stage $5, L$ and $T / 2$ were lower for banana ( 0.1 and $10.9 \mathrm{~h}$, respectively), than for plantain (2.8 and $16.3 \mathrm{~h}$, respectively). Rates of fermentation as well as final gas production were influenced by the variety. Plantain gave faster fermentation rates $\left(\mu_{t=T / 2}\right)$ than banana at stage $1\left(0.100\right.$ vs. $0.0881 / \mathrm{h}$, respectively), whilst final gas production $\left(G_{f}\right)$ was higher in plantain compared to banana at stages 5 and $7(\mathrm{P}<0.01)$. 
A variation in the total SCFA production by rumen microbes during fermentation as well as in the molar ratios of acetate, propionate and butyrate was observed according to the stage of maturation (Table 3). On the other hand, these parameters were not influenced by the variety $(\mathrm{P}>0.05)$. SCFA production ranged from 262 to $304 \mathrm{mg} / \mathrm{g} \mathrm{DM}$ and from 269 to 304 mg DM for banana and plantain, respectively. Whatever the variety, these contents were higher at stage 1 and remained more or less similar between stages 5 and 7 . For both varieties, the molar proportion of acetate increased from 0.75 to approx 0.80 with maturation to the expense of butyrate which decreased from 0.16 to 0.09 for banana and from 0.18 to 0.10 for plantain $(\mathrm{P}<0.001)$.

Finally, IVDMD was only influenced by the maturation stage $(\mathrm{P}=0.002)$ from 0.82 to 0.90 and from 0.86 to 0.90 for banana and plantain, respectively. ME and OMD ranged from 7.7 to $9.7 \mathrm{MJ} / \mathrm{kg} \mathrm{DM}$ and from 0.589 to 0.703 respectively. Both parameters were highly influenced by variety and stage of maturation (Table 4). Moreover, for ME and OMD, interactions between the stage and the variety were observed $(\mathrm{P}<0.05)$, as a consequence of the constant decrease with increasing maturation of banana peels values vs. the decrease in ME and OMD values between stage 1 and stage 5 followed by an increase between stage 5 and stage 7 for plantain peels.

\section{Discussion}

The ME values calculated in this study indicate that banana and plantain peels have energy values that are in the range of other fruit by-products such as oranges peels (Mekasha et al., 2002), citrus peels (Aregheore, 2000; Bampidis and Robinson, 2006) and cassava peels (Aregheore, 2000) and for pods of Enterolobium cyclocarpum (Babayemi, 2006). As hypothesised, both maturation stages and variety influenced the fermentation patterns of the 
peels. Plantain peels appeared of higher energy value as ruminant feed than banana, at least for the varieties considered in this study. Green peels (stage 1) were more energetic than ripe fruits peel (stage 5 and 7).

The main influence of both variety and maturation on fermentability and energy value of the peels seems to be linked to the numerous alterations undergone by the carbohydrate (CHO) fraction, including starch and fibre. The reduction in fermentation rate, measured through the fractional rate of degradation $\left(\mu_{t=T / 2}\right)$ and the reduction in final gas production during maturation is a consequence of the fact that at greener stages (stage 1), to total content of readily fermentable carbohydrates (i.e. sum starch and free sugars) is higher compared with the two later stages (5 and 7). The latter stages yield peels which are richer in slower fermentable carbohydrates such as NDF and ADF (Noziere et al., 2010). With high lignification, the carbohydrates of the ADF fraction for instance are less accessible to bacteria and their fermentation requires more time-consuming enzymatic process which lead to lower energy recovery for the bacteria (Bindelle et al., 2007). To support this assumption, the correlations displayed in Table 5 show that the starch content induced fermentation that started after a longer incubation time (higher $L$ and $T / 2$ ), but once the fermentation was going on, it was faster and more extended (higher $\mu_{t=T / 2}$ and $G_{f}$ ). This is consistent with observations made by Bindelle et al. (2007) who showed that resistant starch from potatoes induced longer lag times $(L)$ than the other readily fermentable carbohydrates, i.e. simple sugars and oligosaccharides, due to slow hydration process required before the bacteria can actually hydrolyze the starch chains to ferment the constitutive glucose units. It could also be a consequence of delayed fermentation induced by transitorily storage of starch granules by ruminal protozoa (Noziere et al. 2010). Conversely, the higher free sugars contents in ripe peels reduced fermentation lag time. In mature peels, the proportion of these highly fermentable $\mathrm{CHO}$ is similar for plantain and lower for banana. In both cases starch and free 
sugar contents are counterbalanced by the increased lignifications of the fibrous fraction of mature peels (increased ADF contents) observed in this study as well as by Happi Emaga et al. (2008a) with other varieties, yielding lower final gas production than green peels. This was highlighted in this study by the absence of significant correlation between ME, OMD and IVDMD, on one side, and starch or free sugars contents, on the other side. It was also illustrated by the negative correlation between ME, OMD and IVDMD and the ADF content ( $\mathrm{r}$ ranging from -0.79 to -0.99 ) and the positive correlation to the hemicellulose content $(\mathrm{r}$ ranging from 0.76 to 0.85 ). Hemicellulose is calculated as the difference between NDF and ADF content. It represents the fibre fraction that is not resistant to acid detergent treatment and is therefore readily fermented by rumen bacteria, compared to the cellulose content of the ADF fraction, yielding faster fermentation, thus releasing energy faster for the animal through SCFA production.

The changes in the $\mathrm{CHO}$ composition of the peels are also reflected in the SCFA profiles after fermentation. SCFA are important to consider as they contribute extensively to the energy supply of the animal. Propionate proportion increased slightly with maturation, whereas that of the butyrate decreased significantly from stage 1 to stage 5 . This reduction is likely related to starch hydrolysis during maturation, as starch is known to favour butyrateproducing microbes.

With higher ME content and butyrate-production, green peels show thus a greater interest as ingredient for ruminants especially in dairy production, as butyrate is the main precursor in the synthesis of milk fat. This is an opposite results to those obtained in singlestomach animals. Tartrakoon et al. (1999) observed that in pigs ME of green banana peels was lower than that of ripe peels (2775 vs. $3377 \mathrm{kcal} / \mathrm{kg}$ respectively). As these authors ascribed this reduction in digestibility to the influence of tannins in the green peels, further research should be conducted on the influence of the variety and the maturity of peels of 
Musa sp. on rumen fermentation with a special focus on the changes in tannins composition. Tannins have indeed the property to make $\mathrm{pH}$ dependent complexes with proteins and might thus decrease dietary protein fermentation in the rumen, increasing the contribution of the diet to protein supply in the intestine. This is particularly useful for dairy cows during the peak of milk production. The influence of maturity and variety on nutritive value in other species such as pigs should also deserve attention. Nevertheless, it can already be concluded from this study that due to variation higher than $15 \%$ in terms of ME contents as measured using an in vitro method, different energy values should be considered when using Musa sp. peels in ruminant diets, depending on the maturation stage and the variety of the fruit.

Acknowledgments T. Happi Emaga was funded by the Commission universitaire pour le Développement (CUD, CIUF, Brussels, Belgium). The authors are also grateful to the technical staff of the laboratory of postharvest technology (CARBAP, Cameroon). 


\section{References}

AOAC. 1990. Official Methods of Analysis. 15th ed. (Association of Official Analytical Chemists, Arlington, VA)

Aregheore, E.M., 2000. Chemical composition and nutritive value of some tropical byproduct feedstuffs for small ruminant-in vivo and in vitro digestibility. Animal Feed Science and Technology, 85, 99--109

Babayemi, O., 2006. Antinutritional factors, nutritive value and in vitro gas production of foliage and fruit of Enterolobium cyclocarpum. World Journal of Zoology, 1, 113--117

Bampidis, V.A. and Robinson, P.H., 2006. Citrus by-products as ruminant feeds: A review. Animal Feed Science and Technology, 128, 175--217

Bindelle, J., Buldgen, A., Wavreille, J., Agneesens, R., Destain, J.P., Wathelet, B. and Leterme, P., 2007. The source of fermentable carbohydrates influences the in vitro protein synthesis by colonic bacteria isolated from pigs. Animal, 1, 1126--1133

Bugaud, C., Alter, P., Daribo, M.O. and Brioullet, J.M., 2009. Comparison of the physicochemical characteristics of a new triploid banana hybrid, FLHORBAN 920, and the Cavendish variety. Journal of the Science of Food and Agriculture, 89, 407--413

FAOSTAT, 2010. FAOSTAT Available from http://faostat.fao.org (accessed July 14th 2010 )

France, J., Dhanoa, M.S., Theodorou, M.K., Lister, S.J., Davies, D.R., Isac. D., 1993. A model to interpret gas accumulation profiles associated with in vitro degradation of ruminant feeds, Journal of Theoretical Biology, 163, 99--111

González-Montelongo, R., Lobo, M.G. and González, M., 2010. Antioxidant activity in banana peel extracts: Testing extraction conditions and related bioactive compounds.Food Chemistry. 119, 1030--1039 
Happi Emaga, T., Andrianaivo, R.H., Wathelet, B., Tchango Tchango, J. and Paquot, M., 2007. Effects of the stage of maturation and varieties on the chemical composition of banana and plantain peels. Food Chemistry, 103, 590--600

Happi Emaga, T.; Robert, C., Ronkart, S.N., Wathelet, B. and Paquot, M., 2008a. Dietary fibre components and pectin chemical features of peels during ripening in banana and plantain varieties. Bioresource Technology, 99, 4346--4354

Happi Emaga, T., Wathelet, B. and Paquot, M., 2008b. Changements texturaux et biochimiques des fruits du bananier au cours de la maturation. Leur influence sur la préservation de la qualité du fruit et la maîtrise de la maturation. Biotechnology, Agronomy, Society, and Environment 12, 89--98

ISO 10520, 1997. Native starch-determination of starch content-Ewers polarimetric method (International Organization for Standardization,Geneva)

Makkar, H.P.S., 2004. Recent advances in the in vitro gas method for evaluation of nutritional quality of feed resources. In: FAO (ed), Assessing quality and safety of animal feeds (FAO, Rome), 55--88

Mekasha, Y., Tegegne, A., Yami, A. and Umunna, N.N., 2002. Evaluation of nonconventional agro-industrial by-products as supplementary feeds for ruminants: in vitro and metabolism study with sheep. Small Ruminant Research, 44, 25--35

Menke, K.H. and Steingass, H., 1988. Estimation of the energetic feed value obtained from chemical analysis and in vitro gas production using rumen fluid. Animal Research Development 28, 7--55

Negesse, T., Makkar, H.P.S. and Becker, K., 2009. Nutritive value of some non-conventional feed resources of Ethiopia determined by chemical analyses and an in vitro gas method. Animal Feed Science and Technology, 154, 204--217 
Nozière, P., Ortigues-Martya, I., Lonckea, C. and Sauvant, D., 2010. Carbohydrate quantitative digestion and absorption in ruminants: from feed starch and fibre to nutrients available for tissues. Animal, 4, 1057--1074

Tartrakoon, T., Chalearmsan, N., Vearasilp, T. and ter Meulen, U., 1999. The nutritive value of banana peel (Musa sapieutum L.) in growing pigs. In: Proceedings of the Deutscher Tropentag 1999, Berlin, 1999 (Humboldt University of Berlin and ATSAF, Berlin), CDROM 
Figure 1 Gas production curves of banana and plantain peels at 3 maturation stages (1, 5 and 7) modelled according to France et al. (1993)

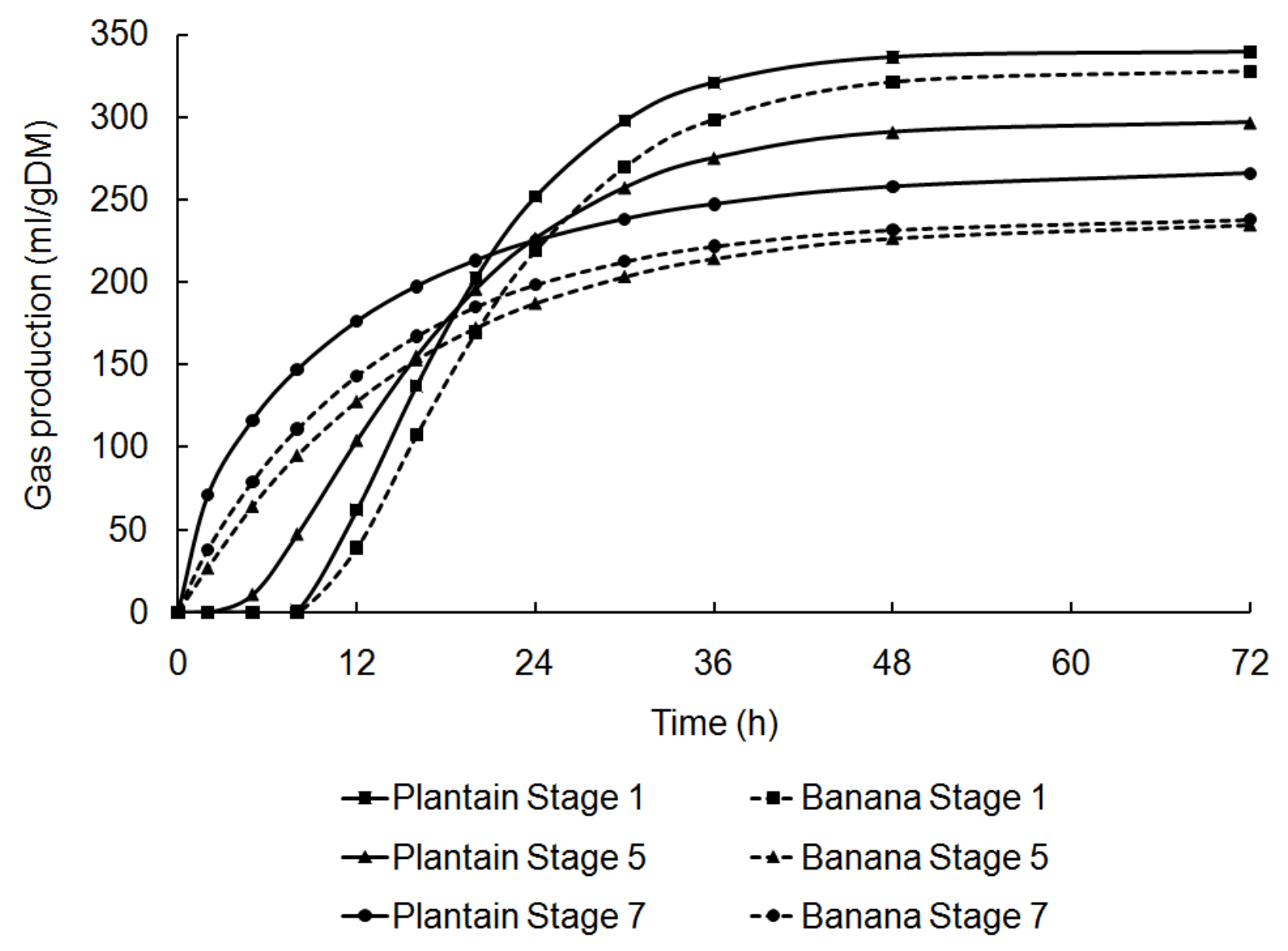


Table 1 Chemical composition (\% DM) of banana and plantain peels at different maturation stages $(1,5,7)$

\begin{tabular}{lcccccc}
\hline Nutrient & \multicolumn{3}{c}{ Plantain (BE) } & \multicolumn{3}{c}{ Banana (Ykm5) } \\
& 1 & 5 & 7 & 1 & 5 & 7 \\
\hline Crude protein $^{1}$ & 8.1 & 8.4 & 8.6 & 6.9 & 7.4 & 7.9 \\
Crude fat $^{1}$ & 2.2 & 3.7 & 3.6 & 6.3 & 8.6 & 10.9 \\
Total ash $^{1}$ & 6.4 & 7.5 & 7.4 & 10.4 & 10.8 & 10.7 \\
Starch $^{1}$ & 39.3 & 24.0 & 0.1 & 14.0 & 12.6 & 2.6 \\
TDF $^{1}$ & 35.9 & 35.7 & 37.3 & 49.9 & 51.9 & 47.9 \\
IDF $^{1}$ & 29.7 & 30.4 & 31.3 & 36.3 & 39.9 & 35.2 \\
SDF $^{1}$ & 6.2 & 5.3 & 6.0 & 13.6 & 12.0 & 12.7 \\
Free sugars $^{1}$ & 4.3 & 23.5 & 38.3 & 1.4 & 23.0 & 33.2 \\
NDF & 20.6 & 23.6 & 21.5 & 27.8 & 31.3 & 29.0 \\
ADF & 14.3 & 19.1 & 21.1 & 22.5 & 30.7 & 28.6 \\
Cellulose & 6.4 & 7.1 & 6.1 & 15.2 & 15.7 & 15.6 \\
Hemicellulose & 6.3 & 4.5 & 0.3 & 5.3 & 0.6 & 0.4 \\
Lignin & 7.9 & 12.0 & 15.0 & 7.3 & 15.0 & 13.3 \\
\hline
\end{tabular}

${ }^{1}$ Previously published in Happi Emaga et al. (2007) 
Table 2 Kinetic parameters of gas production modelled according to France et al. (1993) of banana and plantain peels at 3 maturation stages incubated with a rumen fluid inoculum

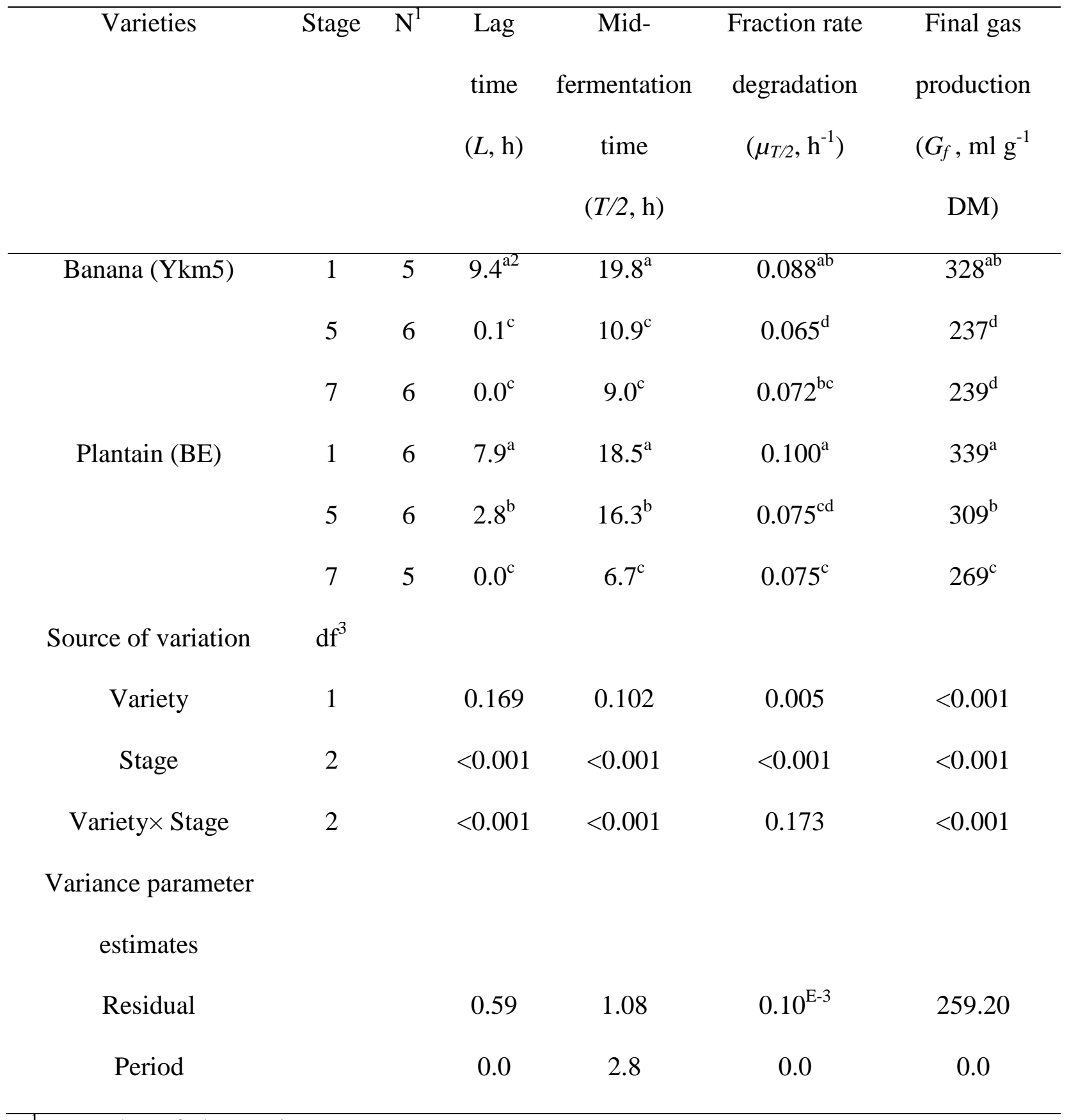

\footnotetext{
${ }^{\mathrm{I}} \mathrm{N}$, number of observations

${ }^{2}$ For one parameter, means followed by different letters in the columns differ at a significance level of 0.05

${ }^{3} \mathrm{df}$, degrees of freedom
} 
Table 3 Total short-chain fatty acid (SCFA) and molar proportions (acetate, propionate and butyrate) of banana and plantain peels at 3 maturation stages incubated for $72 \mathrm{~h}$ with a rumen fluid inoculum

\begin{tabular}{|c|c|c|c|c|c|c|}
\hline \multirow[t]{2}{*}{ Varieties } & \multirow{2}{*}{$\begin{array}{c}\text { Maturation } \\
\text { stage }\end{array}$} & \multirow[t]{2}{*}{$\mathrm{N}^{1}$} & \multirow{2}{*}{$\begin{array}{l}\text { Total SCFA } \\
(\mathrm{mg} / \mathrm{g} \mathrm{DM})\end{array}$} & \multicolumn{3}{|c|}{ Molar ratio $(\%)$} \\
\hline & & & & Acetate & Propionate & Butyrate \\
\hline \multirow[t]{3}{*}{ Banana (Ykm5) } & 1 & 5 & $303.7^{\mathrm{a}^{2}}$ & $75.4^{\mathrm{de}}$ & $8.8^{\mathrm{cd}}$ & $15.7^{\mathrm{ab}}$ \\
\hline & 5 & 6 & $262.2^{\mathrm{d}}$ & $79.9^{\mathrm{bc}}$ & $10.2^{\mathrm{ab}}$ & $9.7^{\text {de }}$ \\
\hline & 7 & 6 & $264.6^{\mathrm{d}}$ & $81.7^{\mathrm{a}}$ & $9.7^{\mathrm{bc}}$ & $8.5^{\mathrm{e}}$ \\
\hline \multirow[t]{3}{*}{ Plantain (BE) } & 1 & 6 & $303.6^{\mathrm{a}}$ & $74.6^{\mathrm{e}}$ & $7.8^{\mathrm{de}}$ & $17.5^{\mathrm{a}}$ \\
\hline & 5 & 6 & $268.9^{b c}$ & $80.7^{\mathrm{b}}$ & $7.5^{\mathrm{e}}$ & $11.7^{\mathrm{bc}}$ \\
\hline & 7 & 5 & $282.2^{\mathrm{ab}}$ & $78.8^{\mathrm{d}}$ & $11.0^{\mathrm{a}}$ & $10.0^{\mathrm{cd}}$ \\
\hline Source of variation & $\mathrm{df}^{3}$ & & & & & \\
\hline Variety & 1 & & 0.249 & 0.341 & 0.181 & 0.113 \\
\hline Stage & 2 & & $<0.001$ & $<0.001$ & 0.021 & $<0.001$ \\
\hline Variety $\times$ Stage & 2 & & 0.722 & 0.462 & 0.053 & 0.983 \\
\hline \multicolumn{7}{|l|}{ Variance parameter } \\
\hline \multicolumn{7}{|l|}{ estimates } \\
\hline Residual & & & 374.0 & 0.0 & 0.0 & 0.0 \\
\hline Period & & & 539.1 & 0.0 & 0.0 & 0.0 \\
\hline
\end{tabular}

\footnotetext{
${ }^{\mathrm{I}} \mathrm{N}$, number of observations

${ }^{2}$ For one parameter, means followed by different letters in the columns differ at a significance level of 0.05

${ }^{3} \mathrm{df}$, degrees of freedom
} 
Table 4. In vitro dry matter digestibility (IVDMD) after $72 \mathrm{~h}$ of fermentation with a rumen inoculum and metabolizable energy (ME) and organic matter digestibility (OMD) calculated according to Menke and Steingass (1998) of banana and plantain peels at 3 maturation stages

\begin{tabular}{|c|c|c|c|c|c|}
\hline Variety & Stage & $\mathrm{N}^{1}$ & $\begin{array}{l}\text { IVDMD } \\
(-)\end{array}$ & $\begin{array}{l}\mathrm{ME} \\
(\mathrm{MJ} / \mathrm{kg} \mathrm{DM})\end{array}$ & $\begin{array}{l}\text { OMD } \\
(-)\end{array}$ \\
\hline \multirow[t]{3}{*}{ Banana (Ykm5) } & 1 & 5 & $0.90^{\mathrm{a} 2}$ & $8.8^{\mathrm{d}}$ & $64.6^{\mathrm{de}}$ \\
\hline & 5 & 6 & $0.82^{\mathrm{c}}$ & $7.7^{\mathrm{f}}$ & $58.9^{\mathrm{f}}$ \\
\hline & 7 & 6 & $0.86^{\mathrm{b}}$ & $8.1^{\text {ef }}$ & $62.7^{\mathrm{e}}$ \\
\hline \multirow[t]{3}{*}{ Plantain (BE) } & 1 & 6 & $0.90^{\mathrm{a}}$ & $9.7^{\mathrm{a}}$ & $70.3^{\mathrm{a}}$ \\
\hline & 5 & 6 & $0.88^{\mathrm{ab}}$ & $9.2^{\mathrm{bc}}$ & $66.6^{\mathrm{bc}}$ \\
\hline & 7 & 5 & $0.86^{\mathrm{b}}$ & $8.9^{\mathrm{cd}}$ & $64.5^{\mathrm{cd}}$ \\
\hline Source of variation & $\mathrm{df}^{3}$ & & & & \\
\hline Variety & 1 & & 0.060 & $<0.001$ & $<0.001$ \\
\hline Stage & 2 & & 0.002 & $<0.001$ & $<0.001$ \\
\hline Variety $\times$ Stage & 2 & & 0.069 & 0.022 & 0.004 \\
\hline
\end{tabular}

Variance parameter estimates

$\begin{array}{lccc}\text { Residual } & 0.00 & 0.09 & 3.94 \\ \text { Period } & 0.0 & 0.3 & 10.6\end{array}$

${ }^{1} \mathrm{~N}$, number of observations

${ }^{2}$ For one parameter, means followed by different letters in the columns differ at a significance level of 0.05

${ }^{3} \mathrm{df}$, degrees of freedom 
Table 5. Pearson's correlation coefficients between chemical composition and kinetic parameters of gas production modelled according to France et al. (1993), total short-chain fatty acids (SCFA) production and molar ratio, in vitro dry matter digestibility (IVDMD) after 72 h of fermentation with a rumen inoculum and metabolizable energy (ME) and organic matter digestibility (OMD) calculated according to Menke and Steingass (1998) of banana and plantain peels at 3 maturation stages $(n=6)$

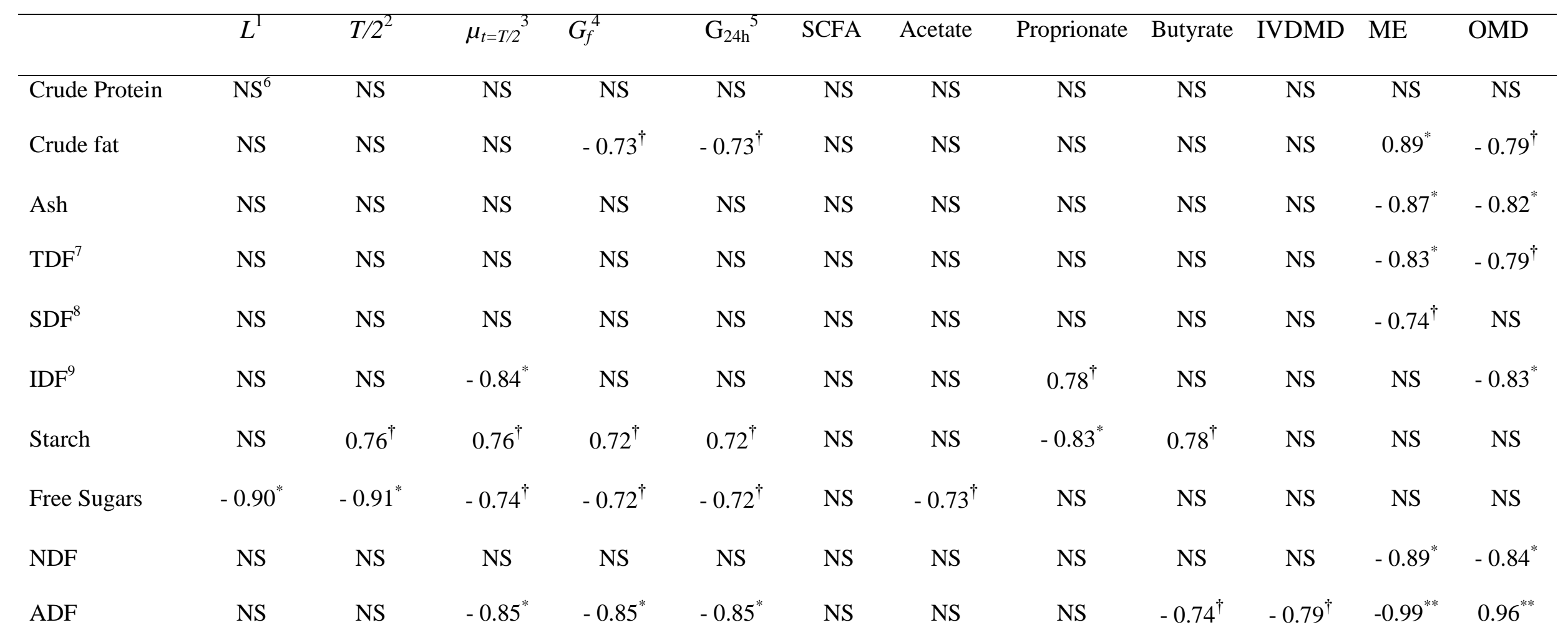




\begin{tabular}{lcccccccccccccccc} 
Cellulose & NS & NS & NS & NS & NS & NS & NS & NS & NS & NS & $-0.84^{*}$ & $-0.77^{\dagger}$ \\
Hemicellulose & $0.91^{*}$ & $0.95^{* *}$ & $0.90^{*}$ & $0.94^{* *}$ & NS & $0.74^{\dagger}$ & $-0.73^{\dagger}$ & $-0.86^{*}$ & $0.93^{* *}$ & $0.85^{*}$ & $0.76^{\dagger}$ & $0.77^{\dagger}$ \\
Lignin & $-0.97^{* *}$ & $-0.93^{* *}$ & $-0.89^{*}$ & $-0.89^{*}$ & $-0.89^{*}$ & $-0.83^{*}$ & $0.80^{*}$ & NS & $-0.92^{* *}$ & $-0.87^{*}$ & NS & NS \\
\hline
\end{tabular}

${ }^{1} L$, lag time

${ }^{2} T / 2$, half-time to asymptote

${ }^{3} \mu_{T / 2}$, fractional rate of degradation

${ }^{4} G_{f}$, gas final volume

${ }^{5} \mathrm{G}_{24 \mathrm{~h}}$, gas production after $24 \mathrm{~h}$ of fermentation

${ }^{6} \mathrm{NS}$, not significant; ${ }^{\dagger}, \mathrm{P}<0.10 ;{ }^{*}, \mathrm{P}<0.05 ;{ }^{* *}, \mathrm{P}<0.01$

${ }^{7}$ TDF, total dietary fibre

${ }^{8} \mathrm{SDF}$, soluble dietary fibre

${ }^{9} \mathrm{IDF}$, insoluble dietary fibre 
